\title{
ALLAH DAN ALAM
}

\author{
Ledy Manusama
}

\begin{abstract}
In the narrative of the Bible, human was created after all objects and creature are first created by God. Thus the real human is the youngest creatures. And indeed, the human could live well because their previous creations, likes the Earth, atmosphere objects, all kinds of plants and animals. Without them, the human would not be able to survive. It means, human can live because the first creation. And until now they could live by the creations. How ever with the progress, the human without realizing becomes a destroyer of creation itself. If in the previous, through the gathering, the human only hunt for food as needed, then the subsequent development of human trying to exploit this natural greedy. The human considers himself as the center of the universe (anthroposentrisme). Then all creation orientation considered to be for humans to ignore this aspect of preservation of nature itself. The human forgets that they can be because it depends on the universe. Human may also forget that God is the creator of the universe presents creations have displeased both humans for survival, they forgot by destroying their nature means the man temporarily and continue to undermine the existence of God as manifested in the presense of nature and difference to nature is difference to God, the human responsible fully to God as a creator who gives the mandate to maintain and manage natural to humans. This papers describes the concept of God and Nature must be continue to build awareness of people and especially Christianity under the responsibility of maintain and manage the natural according to his faith learning.
\end{abstract}

Keywords: God, Man, Nature

\begin{abstract}
Abstrak
Dalam narasi Kitab Suci, manusia diciptakan setelah semua benda dan makhluk diciptakan terlebih dahulu oleh Allah.Dengan demikian manusia sebenarnya makhluk ciptaan yang bungsu.Dan memang, selanjutnya manusia bisa hidup dengan baik berkat adanya ciptaan-ciptaan sebelumnya, sebutlah beberapa di antaranya, seperti bumi, bendabenda langit, segala macam tumbuhan, maupun segala macam hewan. Tanpa mereka, manusia tak akan bisa bertahan hidup. Artinya, manusia bisa hidup karena ciptaaan yang ada terlebih dahulu.Dan sampai sekarang manusia hanya bisa hidup karena ciptaanciptaan tersebut. Namun seiring perkembangan, sadar tak sadar manusia menjadi perusak alam ciptaan itu sendiri.Jika dahulu pada masa meramu, manusia hanya berburu makanan
\end{abstract}


seperlunya, maka perkembangan selanjutnya manusia berusaha mengeksploitasi alam ini secara rakus.Manusia menganggap dirinya sebagai pusat alam semesta ini (anthroposentrisme).Maka segala orientasi ciptaan dianggap hanya untuk manusia dengan mengabaikan aspek kelestarian alam itu sendiri.Manusia lupa bahwa dirinya bisa berada karena bergantung pada alam semesta.Manusia mungkin juga lupa bahwa Allah pencipta alam semesta menyediakan ciptaan yang telah dipandangNya baik bagi manusia guna kelangsungan hidupnya. Manusia lupa bahwa dengan merusak alam sesungguhnya manusia sementara dan terus merusak eksistensi Allah yang termanifestasi pada kehadiran Alam, manusia lupa bahwa ketidakpeduliannya kepada alam adalah ketidakpeduliannya kepada Allah, manusia bertanggungjawab sepenuhnya kepada Allah pencipta yang memberikan mandat memelihara dan mengelola alam kepada manusia.

Tulisan ini memaparkan konsep Allah dan Alam yang berupaya membangun kesadaran manusia khususnya kekristenan dalam tanggungjawab menjaga dan mengelola alam sesuai ajaran imannya.

Kata Kunci : Allah, Manusia, Alam

\section{Pendahuluan}

Agama-agama secara universal mengakui adanya kuasa yang adikodrati atau supra natural atau penguasa tunggal alam semesta yang kemudian oleh beberapa agama besar, Islam, Yahudi, Kristen, disebut dengan nama Allah yang diyakini adalah pencipta alam semesta dan segenap isinya. Di dalam doktrin agama Kristen Protestan, alam adalah wujud dari kehadiran Allah, gambaran kemahakuasaan Allah yang transenden, gambaran pemeliharaan Allah (providensia Allah) yang menyediakan segala kebutuhan ciptaannya, pangan, sandang, dan lain-lain yang merupakan kebutuhan manusia. Dengan sederhana, dapat dikatakanmelalui alam, misteri atau keberadaan Allah diselami oleh manusia.

Sejarah perkembangan manusia memberi catatan bahwa manusia tradisional cenderung menjaga alam. Alam dilihat sebagai yang sacraldengannya manusia membangun hubungan yang harmoni yakni subyek-subyek dimana 
kedudukan manusia dengan alam adalah kedudukan yang sejajar. Alam lalu menyediakan kebutuhan manusia dengan kelimpahan, udara yang bersih, tanah yangsubur, hutan yang rimbun, air yang bersih. Namun, manusia tradisionalmengalami perubahan demi perubahan menuju manusia modern, kurang bahkan tidak lagi membangun hubungan yang harmoni dengan alam, karena alasan-alasan yang tak dapat dihindari oleh manusia. Pemenuhan kebutuhan manusia menjadi hal yang prioritas, ketidakseimbangan pun tercipta antara manusia dengan alam. Kepentingan alam, diabaikan demi kepentingan manusia, alam sebagai manifestasi kehadiran Allah yang memelihara manusia, cenderung dirusak oleh manusia sendiri.Akibatnya, malapetaka tak jarang dihadapi manusia akibat bencana yang didatangkan oleh alam.

Tulisan ini memaparkan konsep Allah dan Alam yang seyogyanya terus membangun kesadaran manusia dalam tanggungjawab untuk menjaga dan mengelola alam sesuai ajaran imannya, yakni bagaimana manusia modern memahami hakikat Allah dalam alam secara teoritis dan secara praktis pemaknaan akan Allah dalam hubungannya dengan memperlakukan alam secara tepat sebagai penghayatan iman.Manusia semestinya berpaling kembali kepada Sang Pencipta untuk memulihkan relasi yang telah rusak itu.

\section{KonsepAllah}

\subsection{Allah Adalah Tuhan Segala Sesuatu ${ }^{\mathrm{i}}$}

Hingga sekitar tahun 200 S.T.U sudah menjadi kebiasaan agar tidak pernah mengucapkan nama yang sebenarnya dari Allah dalam Kitab Suci, Yahweh dan sebagai gantinya selalu menyebut Adonai atau Tuhan (Lord). Kebiasaan yang bersifat tetap ini, pada tahun 200 S.T.U diperlihatkan oleh Septuaginta, terjemahan Kitab Suci Ibrani dalam bahasa Yunani yang tidak mentransliterasi kata Yahweh, tetapi menggantinya dengan kata Yunani Kurios untuk Tuhan. Anggapan bahwa penyebutan nama Allah sebagai suatu hal yang memungkinkan pelanggaran atas perintah untuk tidak menyebut namaNya dengan sia-sia merupakan karakteristik kesalehan Ibrani.Adalah sesuai bila "Tuhan" telah dipilih 
untuk menggantikan nama itu sebab "tuhan" dianggap sebagai penjelasan yang bersifat unggul tentang Allah dalam kitab Suci. Ia adalah Tuhan Allah, Tuhan segala sesuatu, yaitu Tuhan atas langit dan bumi, Tuhan atas semua makhluk supranatural, Tuhan atas semua manusia dan suku bangsa. Ia tak terlampaui dan tak dapat dilampaui. Alkitab tidak mulai secara deduktif, dari klaim-klaim tentang ketuhanan Allah ke suatu penyebutan yang rinci atas segala macam hal, di mana Dia adalah Tuhan atas semuanya. Sebaliknya kitab suci mengembangkan klaimnya secara kontekstual.Ketika Allah dibandingkan dengan makhluk atau kekuasaan apapun yang natural maupun supranatural, Allah tetap dikatakan mengatasi makhluk atau kekuasaan tersebut.

Yang menjadi pusat dalam kesaksian-kesaksian Alkitabiah tentang penciptaan adalah bahwa tak ada sesuatu pun yang memiliki kekuasaan yang melampaui Allah.Keyakinan ini tampak dalam penafsiran yang biasa atau pasal pertama kitab Kejadian bahwa Allah menciptakan dunia dari yang tidak ada.Sebelum Allah menciptakan dunia, yang ada hanya kehampaan, kekosongan. Disini kekuasaan Allah atas segala sesuatu dengan jelas ditegaskan, tetapi juga ditegaskan dalam suatu penafsiran alternatif yang menolak pandangan tentang penciptaan, dari penciptaan: "ketika Allah mulai menciptakan langit sesuatu yang hampa. Suatupembacaan yang berbeda atas ayat pertama kitab Kejadian menyatakan kemungkinan adanya materi sebelum Allah menciptakan langit dan bumi, bumi tidak berbentuk dan kosong" adalah sama makna keimanannya bagi orang Ibrani seperti ayat yang lebih akrab "pada mulanya Allah menciptakan langit dan bumi(Kej 1:1).

Allah mentransendensikan alam semesta dalam cara lain. Alam semesta bukanlah suatu bagian dari Allah sebagaimana yang ada dalam panteisme.Alam semesta adalah ciptaanNya, hasil karyaNya.Bumi adalah tumpuan kakiNya (Yes 66:1) dan bukan tubuhNya.Angin dan badai bukanlah energi atau kekuasaan Allah sebagaimana yang terdapat dalam beberapa tradisi kuno, melainkan karya tanganNya."Langit menceritakan kemuliaan Allah" (Mzm 19:2), tetapi benda- 
benda itu bukanlah kemuliaanNya.Segenap tatanan alam tidak dikeramatkan, tetapi dijadikan sebagai alat Allah.

Lebih lanjut lagi, Allah tidak berada di bawah kekuasaan yang bersifat impersonal atau kemutlakan alamiah apa pun. Tak ada kemutlakan eksternal, takada takdir, tak ada providensia (pemelihara yang baik) yang terhadapnya Dia tunduk.Dia adalah penguasa dan juga pencipta segala sesuatu.Didalam keberadaanNya, pikiran dan kesadaranNya tak tertandingi.Kebijaksanaan dan kehendakNya tidak dikendalikan, tetapi mengendalikan."Tuhanlah yang menjadikan bumi dengan kekuatanNya, yang menegakkan dunia dengan kebijaksanaanNya dan yang membentangkan langit dengan akal budiNya” (Yer 51:15).Bahkan, hukum pun tak memiliki kekuasaan atas kehendakNya dan kebijaksanaanNya.

\subsection{Allah adalah Pencipta}

Kata pencipta berasal dari terjemahan kata "poieten"dalam bahasa Yunani, sedangkan kata Latinnya adalah “creatorem”.Kedua kata ini benar-benar merupakan terjemahan dari kata "pencipta”.Dalam gereja mula-mula istilah menciptakan dimengerti dalam arti yang paling ketat yaitu; "menciptakan sesuatu tanpa bahan sama sekali".Alkitab pun tak selalu memakai kata "bara” (Ibr)atau kata "kitzein" (Yun).Dalam arti mutlak bagi pengertian menciptakan, namun ada dua istilah lainnya yang dipakai secara bersinonim dengan kata menciptakan adalah "membuat" (Ibr. asah; Yun. poiein) dan "membentuk" (Ibr. yatsar; Yun. plasso). Kata membuat dipakai dalam tiga pengertian yang dijelaskan sebagai berikut; tentang penciptaan pertama dalam Kej. 2:4; Ams 16:4; Kis 17:24. Kata membentuk dipakai untuk maksud yang sama tentang penciptaan pertama (Mzm 90:2).

Penciptaan adalah permulaan dan dasar dari semua pernyataan Ilahi dan sebagai akibatnya juga merupakan dasar dari semua kehidupan etis dan religius.Doktrin penciptaan menekankan fakta bahwa Allah adalah asal mula dari 
segala sesuatu dan bahwa segala sesuatu adalah kepunyaanNya dan berhadapan dengannya. Iman gereja terhadap penciptaan dunia terlihat dalam kalimat pertama Pengakuan Iman Rasuli yang mengatakan: “Aku percaya kepada Allah Bapa yang Mahakuasa, khalik langit dan bumi..." Pernyataan ini menunjukan adanya pengakuan akan Allah sang pemilik langit dan bumi, atau alam semesta ini. Allah yang dari kuasaNya segala yang ada di alam ini berada.

Mengenai pengertian penciptaan secara sempit penciptaan adalah "tindakan bebas Allah di mana Ia sesuai dengan kehendakNya yang berdaulat dan demi kemuliaanNya sendiri pada mulanya menjadikan keseluruhan alam semesta, baik yang terlihat maupun tidak, tanpa memakai bahan yang telah ada sebelumnya, sehingga menjadikan semuanya ada, yang berbeda dengan diriNya dan senantiasa bergantung kepadaNya".Penciptaan merupakan suatu tindakan dari Allah Tritunggal (Kej 1:1; Yes 40:12; 44:24; 45:12), walaupun Allah Bapa ada di latar depan dalam karya penciptaan, namun dalam 1 Kor 8:6 menunjukan bahwa karya penciptaan adalah karya Allah Putra dan Roh Kudus. Penciptaan adalah merupakan suatu tindakan bebas Allah yang ditentukan atas kehendakNya yang berdaulat. Alkitab mengajarkan bahwa Allah menciptakan segala sesuatu, Ef 1:11; Why 4:11; dan bahwa Ia cukup bagi diriNya sendiri dan tidak tergantung pada makhlukNya sama sekali, Ayub 22:2,3; Kis. 17:25.

Istilah "menciptakan" dipakai dalam dua arti di Alkitab :

1. Penciptaan langsung (creatio immediata)

Penciptaan langsung merupakan tindakan bebas Allah tritunggal.Melalui tindakan ini Allah pada mulanya menciptakan segala sesuatu yang nampak dan yang tidak nampak (semua hal yang berupa benda jugasemua hal yang tidak berupa benda).Untuk kemuliaanNya sendiri.Tanpa memakai bahan yang sudah ada (ex nihilo) sebelum dunia diciptakan atau tanpa sebab-sebab sekunder.Istilah "penciptaan langsung" boleh jadi harus dibatasi pada Kejadian 1:1 dan ayat-ayat lainnya yang menunjuk kepada peristiwa yang sama.Pandangan ini berbeda dengan semua gagasan panteistis yang 
menganggap bahwa ciptaan ini terjadi karena sebab-sebab sekunder dan bukan karena kehendaknya yang bebas.

2. Penciptaan tidak langsung (creatio mediata)

Penciptaan tidak langsung, sebaliknya, merupakan tindakan-tindakan Allah yang juga di sebut "penciptaan", namun yang tidak bermula dari ketiadaan atau "ex nihilo". Melalui tindakan-tindakan ini Allah membentuk, menyesuaikan, menggabungkan, atau mengubah bahan-bahan yang sudah ada.

\subsection{Providentia Allah}

Pandangan Kristen menegaskan bahwa Allah bukan saja telah menciptakan alam semesta dengan segenap sifat dan kekuatannya, dan bahwa ia telah melestarikan segala sesuatu yang telah diciptakanNya itu, tetapi bahwa sebagai Oknum yang kudus, mahamurah, bijaksana serta mahakuasa ia juga menjalankan pengawasan yang berdaulat atas ciptaan-Nya.Pengawasan yang berdaulat ini disebut dengan pemeliharaan.

Secara etimologi, kataprovidence (bahasa Inggris) yang diterjemahkan sebagai pemeliharaan artinya melihat/mengetahui sebelumnya. Dari pemikiran dasar ini maka kata ini kemudian mendapat arti menyediakan untuk masa depan. Akan tetapi, dalam teologi kata "providence" mendapat arti yang lebih khusus lagi yaitu kegiatan berkesinambungan Allah untuk menjadikan segenap peristiwa dibidang fisik, mental, dan moral,melaksanakan rencana yang telah ditetapkanNya, yaitu rencana yang merupakan pola utama Allah dalam menciptakan alam semesta.

Providential dapat dibagi menjadi dua ${ }^{\mathrm{ii}}$ : Pertama:Pemeliharaan. Tuhan memelihara alam seisinya artinya: Tuhan menghindarkan alam dari tenaga-tenaga yang akan merusaknya. Manusia di dalam hal ini juga menjadi gambar Tuhan sebab itu diberi perintah oleh Tuhan supaya Eden dipeliharanya. Selain itu 
memelihara juga berarti: bekerja agar hukum-hukum, aturan-aturan yang ada di alam seisinya tetap berjalan. Maka dari itu pemeliharaan harus dipandang sebagai aktivitas (tindakan) yang sebetulnya seperti di dalam Firman Tuhan dinyatakan antara lain dalam Mazmur 104:30; Yohanes 5:17; Ibrani 1:3.Manusia menjadi alat Tuhan.Kedua, Pemerintahan, Segala sesuatu dalam alam, Allah yang memerintahnya. "Memerintah" artinya: menjuruskan perkembangankepada suatu maksud. Tuhan menjadikan segala sesuatu masing-masing dengan maksudnya sendiri; akan tetapi segala sesuatu tidak berjalan sendiri kepada maksudnya (deisme), melainkan Tuhan yang mengemudikan hingga maksudNya tercapai.

Ini dapat dikatakan tentang alam segenapnya: Tuhan memberi jalan kepada bintang dan sebagainya. Akan tetapi juga tentang manusia, Tuhan juga memberi arah bagi tindakan-tindakanNya, hingga maksud Tuhan di dalam manusia tercapai. Hormat Tuhan akan diperbesar juga oleh manusia. Kerapkali manusia tidak bermaksud untuk memuliakan nama Tuhan, bahkan kerapkali dengan sengaja menentang maksud Tuhan. Tiap-tiap tindakan akan diadili. Akan tetapi maksud Tuhan tentu akan tercapai.

Jadi baik dalam pemeliharaan maupun dalam pemeliharaan Tuhan berkenan memakai manusia sebagai alat.Tuhan memberikan perintahNya yang terang, umpama kepada manusia. Ia memerintahkan ; "Taklukanlah itu, dan berkuasalah atas ikan-ikan...." (Kej 1:28) dan manusia ditempatkan dalam taman Eden, "untuk mengusahakan dan memelihara" (Kej 2:15). Manusia harus memelihara bumi oleh karena kekacauan selalu mengancam akan merusak bumi. Manusia harus mengusahakan bumi agar bumi selalu berkembang kearah maksud Allah.Manusia harus mengkulturkan bumi.Hal ini menjadi lebih terang sesudah pengaruh dosa masuk ke dalam alam semesta dan dunia manusia.

\section{Konsep Alam}

\subsection{Defenisi Alam}

Dalam uraian ini, istilah alam memberi penekanan bertolak dari pikiran Celia Deane-Drummond ${ }^{\mathrm{iii}}$ sebagai acuan pada ciptaan bukan manusia.Terminologi 
yang digunakan mengenai lingkungan hidup atau alam adalah 'ciptaan' (creation).Penggunaan istilah itu bertolak dari keyakinan bahwa lingkungan hidup atau alam diciptakan oleh Allah dan bukan sesuatu yang terjadi dengan sendirinya.Ciptaan adalah suatu istilah iman yang menunjuk pada satu sikap terhadap kenyataan yang oleh Allah dihidupkan.Pengertian itu juga mengandung makna hormat.

Secara eksegetis pengertian penciptaan itu dapat ditafsirkan melalui berbagai cara misalnya: sebagai suatu tindakan Allah yang sekali dan kekal pada awal kejadian alam semesta, atau secara eskatologis yang terarah ke masa depan. Istilah "ciptaan" mencakup segala sesuatu dan menunjuk pada hubungan segala sesuatu itu dengan Allah.Istilah ciptaan juga menunjukkan bahwa dunia ini adalah dunia yang dikasihi dan diselamatkan oleh Allah (Yoh 3:16). ${ }^{\text {iv }}$ Ciptaan adalah dunia yang disebut oleh Alkitab sebagai "langit dan bumi" yang di dalamnya berlangsung kehidupan, baik manusia maupun makhluk lainnya, kehidupan yang terus dipelihara dan diarahkan pada penyempurnaan dalam langit dan bumi yang baru (Why 21). Jadi dalam istilah itu tercakup makna alam baik dari segi ruang dan waktu, baik aspek biologis dan metafisik, baik aspek masa lampau dan masa kini maupun aspek masa depan dari alam ini.

\subsection{Nilai Alam}

Manusia adalah bagian dari "alam" dalam arti manusia ikut serta dalam proses-proses biologis dan fisiologis, sama seperti binatang dan makhluk hidup lainnya. Sebaliknya, manusia juga "terpisah" dari alam karena manusia memiliki kesadaran dan sanggup mengambil keputusan secara sadar tentang cara mengubah alam disekitarnya.

Jika manusia memandang alam sebagai sumber untuk dikelola bagi kepentingan manusia, alam mempunyai nilai instrumental(instrumental value). Kalau manusia memandang bahwa alam memiliki nilai di dalam dan dari dirinya sendiri, alam mempunyai nilai bawaan (inherent value).Nilai bawaan ini sering digunakan oleh etikawan sebagai acuan pada nilai sesuatu, dengan asumsi bahwa 
ada nilai subjek. Misalnya, kayu mempunyai nilai bawaan bagi pemiliknya selama ia ada. Sebaliknya, kalau kita memandang alam punya nilai hakiki (intrinsic value), nilai itu ada terbebas dari manusia atau kehadiran manusia sebagai subjek yang menilai. ${ }^{\mathrm{v}}$

Praksis ekologi Kristen mesti didasarkan pada sebuah pemahaman etis bahwa setiap ciptaan memiliki nilai, tidak hanya karena dapat digunakan demi pemenuhan kebutuhan manusia, tetapi karena memiliki nilai intrinsik dalam dirinya sendiri.Semua ciptaan punya nilai dalam dirinya sendiri. Alasannya: pertama, semua ciptaan secara langsung berelasi dengan Allah, sang Pencipta. Kedua, alam semesta ini diciptakan dan ditransformasikan dalam Yesus Kristus, Kebijaksanaan-Hikmat Allah. Ketiga, seperti kata Bonaventura, setiap ciptaan merupakan pengungkapan diri Allah, artikulasi tercipta dari Sabda Abadi, Kebijaksanaan Allah, Seni Allah, yang nampak dalam dunia. ${ }^{\text {vi }}$

\subsection{Kerusakan Lingkungan Alam}

Berdasarkan defenisi lingkungan alam yang dimaksudkan dalam penulisan ini, maka dapat dikatakan kerusakan lingkungan alam merupakan kerusakan lingkungan hidup yang pada prinsipnya merupakan segala sesuatu yang berada di sekitar manusia apapun bentuknya.Bentuk kerusakan lingkungan hidup yang juga merupakan kerusakan lingkungan alam dapat dibedakan menjadi 2 jenis yaitu :

1. Bentuk Kerusakan LingkunganHidupAkibat Peristiwa Alam Bentuk kerusakan lingkungan alam berdampak pada lingkungan hidup. Contoh: gelombang tsunami, gempa bumi, letusan gunung berapi, angin taufan, merupakan fenomena alam yang dalam sekejap mampumengubah bentuk muka bumi dan menghancurkan kehidupan manusia.

2. Kerusakan Lingkungan Hidup karena Faktor Manusia 
Manusia sebagai penguasa lingkungan hidup di bumi berperan besar dalam menentukan kelestarian lingkungan hidup.Manusia sebagai makhluk ciptaan Tuhan yang berakal budi mampu merubah wajah dunia dari pola kehidupan sederhana sampai ke bentuk kehidupan modern seperti sekarang ini. Namun sayang, seringkali apa yang dilakukan manusia tidak diimbangi dengan pemikiran akan masa depan kehidupan generasi berikutnya. Banyak kemajuan yang diraih oleh manusia membawa dampak buruk terhadap kelangsungan lingkungan hidup.

Adapun beberapa bentuk kerusakan lingkungan hidup karena faktor manusia, antara lain adalah terjadinya pencemaran (pencemaran udara, air, tanah, dan suara) sebagai dampak adanya kawasan industri, terjadinya banjir sebagai dampak buruknya drainase atau sistem pembuangan air, kesalahan dalam menjaga daerah aliran sungai dan dampak pengrusakan hutan, dan terjadinya tanah longsor sebagai dampak langsung dari rusaknya hutan.Untukmenjamin ketersediaan pangan, manusia harus membuka hutan, mengubahnya menjadi area pertanian, yang tak jarang memakai cara-cara bertani yang tak ramah pada alam.

Dalam hal mengamankan ketersediaan pangan, manusia tak segan memakai cara-cara yang tak ramah lingkunganmisalnya penggunaan pestisida kimia yang memusnahkan spesies-spesies lainnya.Di samping merusak alam, sebenarnya cara-cara tersebut berpotensi menghancurkan manusia itu sendiri karena banyak bahan beracun terakumulasi dalam pangan yang dikonsumsi manusia.Sementara itu, untuk keperluan industri, penambangan besar-besaran dilakukan.Mereka membuat lubang-lubang raksasa di perut bumi untuk mengambil biji-biji tambang. Atas namadan pembangunan, alam diperkosa habis-habisan. Semua itu dilakukan dengan dalih untuk kesejahteraan manusia.

\section{Konsep Manusia-Alam}

\subsection{Relasi Manusia-Alam}

Manusia bukanlah pertama-tama makhluk berpikir saja atau makhluk berbadan saja, manusia bukanlah makluk yang begitu saja dipisahkan dari kontak 
sosialnya, manusia tidak dapat dibatasi.Ia merupakan makluk yang bertindak, bertanggung jawab atas kehidupan kodratnya kepada Tuhan dan sesama. Hubungan manusia dengan alam sekitar pada awalnya digambarkan oleh Kitab Suci sangatlah baik.Allah menciptakan sebuah rumah kediaman yang begitu indah dan nyaman bagi manusia. Manusia diserahi kuasa oleh Tuhan untuk memelihara, merawat alam raya yang indah itu agar semuanya selaras, tertib, dan aman.Kedudukan manusia dalam alam raya ini adalah wakil dan penggarap.

\subsection{Penyimpangan Historis: Pandangan Barat mengenai Hubungan Manusia-Alam}

Filsuf dan sejarawan ide-ide Australia terkenal, John Passmore dalam bukunya yang dikenal luas pada 1974: Man's Responsibility for Nature. Dua bab pertama yang terdiri dari analisis tajam mengenai perkembangan dari pandanganpandangan kodrat manusia Barat yang dominan. Ia memberi ciri pandanganpandangan itu sebagai (1) manusia sebagai penguasa lalim; (2) penjagaan; (3) sikap-sikap yang menyatakan bahwa manusia mengembangkan dan menyempurnakan alam. ${ }^{\text {vii }}$

Manusia sebagai penguasa lalim: sesuai dengan tesis White, Passmore menelusuri pandangan manusia sebagai eksploitor dan penakluk yang sembrono sampaiinterpretasi yang secara historis dominan atas Kitab Kejadian di dalam Perjanjian Lama.Manusia sebagai penjaga: ide mengenai "penjagaan" manusia atas bumiPassmore menelusuri sampai Plato dan Filsuf post-Platonik, Iamblichus. Dalam usaha untuk menjelaskan mengapa jiwa manusia yang immaterial dan tak dapat mati akan selalu "membenamkan dirinya dalam materi", Iamblichus (abad ketiga Masehi) menunjuk pada bab dari Plato: "Manusia, kata mereka, dikirim ke bumi oleh Allah "untuk mengurus benda-benda bumi", untuk memperhatikan mereka atas nama Allah.

Mulai abad ketujuh belas, pandangan-pandangan antroposentrik Kristen dan Humanis saling memperkokoh, dan sulit untuk memisahkan, yang cenderung untuk mendukung pertanyaan White bahwa "kita terus hidup sekarang sebagian besarnya dalam konteks dalil-dalil Kristen”. 
Manusia menyempurnakan alam: Passmore melukiskan pandangannya sebagai berikut: Tanggung jawab manusia untuk menyempurnakan alam dengan bekerja sama dengannya (dalam arti bahwa) kita bicara, dalam semangat ini, mengenai suatu bidang yang masih dalam keadaan awalnya sebagai "belum dikembangkan". Untuk "mengembangkan” tanah, menurut pandangan ini, berarti mengaktualisasikan potensi-potensinya, untuk membawa ke terang apa yang ia miliki dalam dirinya sendiri untuk menjadi, dan dengan ini dimaksudkan menyempurnakannya, bagaimana kesempurnaan di nilai: pengandaiannya masih dalam gaya Aristoteles, bahwa alam mencapai kualitas terbaiknya bila memenuhi kebutuhan manusiayaitu, alasan bagi keberadaannya, untuk menjadi apakah potensialitasnya itu. Menyempurnakan alam berarti memanusiawikannya, membuatnya lebih berguna bagi tujuan manusia, lebih dapat dimengerti oleh akal mereka, lebih indah bagi mata mereka ... manusia tidak memenuhi semesta yang dengan berada di dalamnya ... ia membantu menciptakannya.Tahun setelah buku ini muncul, Passmore menarik persetujuannya terhadap antroposentrisme baik dari posisi "kepenjagaan" maupun "manusia menyempurnakan alam".

Demikian antroposentris ini sering dihubungkan dengan pandangan Barat yang melihat lingkungan hidup sebatas maknanya bagi kesejahteraan dan kemakmuran manusia.Manusia Barat menganut pandangan mengenai hubungan diskontinuitas antara manusia dengan alam. Hanya manusia yang subjek, sedangkan alam atau lingkungan adalah objek. Maka alam diteliti, dieksplorasi, lalu dieksploitasi. Maka etika antroposentris ini tidak sejalan dengan etika Kristen yang menekankan adanya kontinuitas antara manusia dengan alam (adam-adamah, homo-humus).

Berbeda dengan pandangan barat, ciri pendekatan terhadap manusia dan alam di Asia. Pada umumnya, dalam tradisi-tradisi religious di Asia ada rasa kekeluargaan yang dalam antara manusia dan alam.Tidak ada pengertian yang bersifat analitis mengenai alam. Sebaliknya hubungan manusia dengan alam dimengerti secara rasional, intuitif, mistis dan estetis.Beberapa tradisi Asia tidak menempatkan manusia di atas alam atau terpisah dari alam, melainkan bagian dari 
alam, yang menopangnya dan ditopang olehnya. Manusia diharapkan hidup dalam hubungan timbal balik dengan alam serta belajar tentang prinsip-prinsip hidup, kebajikan dan kebijaksanaan dari alam. ${ }^{\text {vii }}$

Pada umumnya agama dan filsafat timur memahami hubungan dengan alam demikian.Sementara juga filsafat dan agama barat sebelum timbulnya rasionalisme, memandang hubungan manusia dengan alam sebagai sesama yang setara dan harmonis.

\section{Merenungkan Allah dan Alam}

Dalam perspektif teologi Kristen, memahami alam dan semua krisis yang terdapat di dalamnya tidak dapat dilepaskan dari gambaran yang besar dan utuh tentang hubungan-hubungan eksistensial antara Allah, Sang Pencipta, dan ciptaanNya, contohnya dengan melihat trialektika Allah-manusia-bumi. Allah yang independen, manusia dan bumi yang dependen terhadap Allah sekaligus interdependen antara keduanya. ${ }^{\text {ix }}$

Pandangan manusia untuk menghormati alam lingkungannya belum menjadi tindakan iman. Kalaupun ia melakukan tindakan iman itu, ia hanya melakukannya semata-mata karena terpaksa atau karena keinginan memiliki gaya hidup sehat bukan karena tuntutan iman. Penghargaan manusia terhadap alam ciptaan tergantung pada cara pandang manusia terhadap alam ciptaan itu sendiri.

Merusak alam adalah dosa. Tindakan ini sebenarnya merusak sistem yang berkaitan dengan makhluk ciptaan lainnya. Padahal, semua makhluk ciptaan saling bergantung satu dengan lainnya. Jika satu makhluk rusak, maka hal itu akan berdampak pada makhluk yang lainnya. Maka yang terjadi adalah hilangnya kesejahteraan semesta.

Menurut William Chang ${ }^{\mathrm{x}}$ demi terbentuknya sikap positif menghadapi makhluk ciptaan, maka suasana pertobatan mesti diangkat menjadi wadah pembentukan sikap. Karena suatu pandangan hidup yang berlandaskan pertobatan 
pada Tuhan Yesus memungkinkan manusia untuk memandang Allah sebagai sumber keberadaan sekalian makhluk hidup. Allahlah yang menganugerahkan segala ciptaan kepada umat manusia. Bila tidak memperlakukan alam sebagai karunia Ilahi, maka manusia tidak bisa merasakan penciptaan Allah yang terus menerus di lingkungan kita.

Rasa syukur akan anugerah Allah dalam rupa alam ciptaan itu membuat manusia bertobat dan lebih menghormati alam. Alam sebagai tempat hidup sekaligus sebagai partner dalam menapaki peziarahan hidup. Allah hadir melalui alam ciptaanNya. Maka dengan demikian alam ciptaan mempunyai nilai sakramental dalam dirinya. Karena alam ciptaan mempunyai nilai sakramental dalam dirinya, maka alam ciptaan pun menjadi sarana keselamatan umat manusia dan makhluk ciptaan di dalamnya. Hal ini secara jelas terlihat bahwa antara makhluk-makhluk ciptaan itu terjalin rantai kebutuhan. Salah satu makhluk membutuhkan makhluk lainnya demi terselenggaranya kehidupan makhluk tersebut. $^{\mathrm{xi}}$

Alam adalah titipan dari Allah untuk dimanfaatkan manusia guna memenuhi kebutuhan hidupnya, tetapi sekaligus adalah rumahnya sebagai bentuk pemeliharaan Allah.Maka sumber-sumber alam diberikan kepada manusia tidak untuk diboroskan.Manusia harus menggunakan dan memanfaatkan sumbersumber alam itu secara bertanggung jawab.Pemanfaatan/penggunaan sumbersumber alam haruslah dilihat sebagai bagian dari pelayanan karena manusia tunduk pada Allah sebagai pencipta dan tunduk terhadap pemerintahan Allah. Alam digunakan dengan memerhatikan keseimbangan antara kebutuhan manusia dengan kebutuhan lingkungan, yaitu menjaga ekosistem. Tetapi alam juga digunakan dengan memerhatikan kebutuhan sesama, termasuk generasi yang akan datang.

Memanfaatkan alam adalah bagian dari pertanggungjawaban diberikan/dipercayakan oleh Tuhan kepada manusia (Mat. 25:14-30). Allah telah memercayakan alam ini untuk dimanfaatkan dan dipakai.Untuk dilipatgandakan 
hasilnya, untuk disuburkan, dan dijaga agar tetap sehat sehingga produknya tetap optimal.Oleh karena itu, alam mesti dipelihara dan keuntungan yang didapat dari alam sebagian dikembalikan sebagai deposit terhadap alam.Tetapi juga dipergunakan secara adil dengan semua orang.Ketidakadilan dalam memanfaatkan sumber-sumber alam adalah juga salah satu penyebab rusaknya alam. Sebab mereka yang merasa kurang akan mengambil kebutuhannya dari alam dengan cara yang sering kurang memerhatikan kelestarian alam, juga mereka yang tergoda akan kekayaan melakukan pengurasan sumber alam secara tanpa batas.

Sikap yang tepat memperlakukan alam dapat ditunjukkan dengan sikap hormat dan menghargai (respek) terhadap alam.Tidak berarti alam disembah, tetapi alam dihargai sebagai ciptaan yang dikaruniakan Tuhan untuk memenuhi kebutuhan manusia, sekaligus yang menjadi cerminan kemuliaan Allah.Menghargai alam berarti menghargai Sang Pencipta dan Sang Penebus.Bersama ciptaan lain, manusia adalah sesama ciptaan Tuhan. Meski ia secitra dengan Allah, dia sebenarnya hidup bergantung pada ciptaan-ciptaan lain. Sudah sepantasnya manusiapun menyadari kelebihannya sebagai makhluk dengan menjaga relasi antara dirinya dengan alam, sesama manusia dan Allah Pencipta.

Endnotes:

'Linwood Urban, Sejarah Ringkas Pemikiran Kristen, (Jakarta: BPK Gunung Mulia, 2009), hlm.10-13.

iiR Soedarmo, Ikhtiar Dogmatika, (Jakarta: BPK Gunung Mulia, 2006), hlm.146.

iii Deane Celia-Drummond, Teologi Ekologi, Buku Pegangan, (Jakarta: BPK Gunung Mulia, 2001), hlm.76.

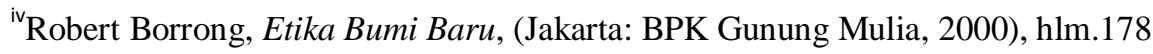

${ }^{\vee}$.Op.cit,Deane Celia-Drummond, hlm.78.

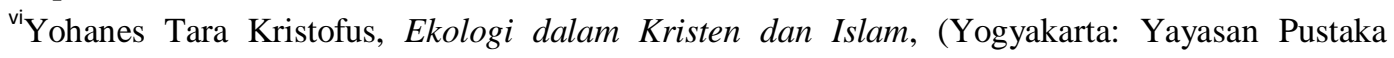
Nusalama, 2008), hlm.124.

vii Tucker Evelyn Mary \& Grim A John,Editor, Agama, Filsafat dan Lingkungan Hidup, (Yogyakarta: Kanisius, 2003), hlm.274.

viii Ibid. 


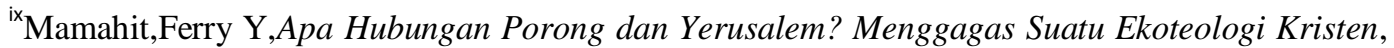
(Veritas, 2007),hlm.9.

${ }^{x}$ Chang William, Moral Lingkungan Hidup, (Yogyakarta: Kanisius, 1989), hlm. 114.

${ }^{x i}$ Awi Tristanto Lukas, Panggilan Melestarikan Alam Ciptaan, (Yogyakarta: Kanisius, 2015), hlm. 94.

\section{DAFTAR PUSTAKA}

Awi Tristanto Lukas, 2015. Panggilan Melestarikan Alam Ciptaan.Yogyakarta: Kanisius.

Borrong Robert, 2000. Etika Bumi Baru. Jakarta: BPK Gunung Mulia.

Chang William, 1989. Moral Lingkungan Hidup. Yogyakarta: Kanisius.

Drummond Deane Celia. 2001.Teologi Ekologi, Buku Pegangan.Jakarta: BPK Gunung Mulia.

Linwood Urban, 2009.Sejarah Ringkas Pemikiran Kristen. Jakarta: BPK Gunung Mulia.

Mamahit,Ferry Y, 2007. Apa Hubungan Porong dan Yerusalem? Menggagas Suatu Ekoteologi Kristen.Veritas.

Soedarmo R, 2006. Ikhtiar Dogmatika. Jakarta: BPK Gunung Mulia.

Tucker Evelyn Mary \& Grim A John, Editor, 2003. Agama, Filsafat dan Lingkungan Hidup, Yogyakarta: Kanisius.

Yohanes Tara Kristofus, 2008. Ekologi dalam Kristen dan Islam. Yogyakarta:Yayasan Pustaka Nusalama. 